\title{
Disordered ultrastructure in lignin-peroxidase- secreting hyphae of the white-rot fungus Phanerochaete chrysosporium
}

\author{
Laura Zacchi, ${ }^{1}$ Ian Morris ${ }^{2}$ and Patricia J. Harvey ${ }^{1}$ \\ Author for correspondence: Patricia J. Harvey. Tel: +44 181331 9972. Fax: +44 1813318305. \\ e-mail:p.j.harvey@greenwich.ac.uk
}

1 School of Chemical and Life Sciences, University of Greenwich, Wellington Street, London SE18 6PF, UK

2 Department of Biology, Imperial College of Science Technology \& Medicine, Prince Consort Road, London SW7 2BB, UK

\begin{abstract}
The practice of exposing liquid cultures of the white-rot fungus Phanerochaete chrysosporium to a pure oxygen atmosphere under conditions of nutrient starvation has been widely adopted to induce lignin peroxidase (LiP) synthesis. Transmission electron microscopy was used to examine hyphal cells of carbonlimited cultures that had been exposed to an atmosphere of pure oxygen, and revealed evidence of a major loss in organization of cellular ultrastructure, which may be attributed to oxygen toxicity. Under some conditions (continuous agitation in air with cellulose as the carbon source) cultures will produce LiP without needing to be exposed to a pure oxygen atmosphere. A similar major loss of cellular ultrastructure was found in hyphal cells from such cultures upon examination. Investigation of the levels of $\mathrm{H}_{2} \mathrm{O}_{2}$, catalase and carbonyl content of intracellular proteins suggests that the latter cultures developed a hyperoxidant state because the rate of supply of carbon from cellulose hydrolysis was insufficient for oxygen homeostasis. The association of LiP with these cultures and with those exposed to an atmosphere of pure oxygen infers that LiP may be triggered in response to oxidant stress.
\end{abstract}

Keywords: cellulose, lignin peroxidase, Phanerochaete chrysosporium, oxidant stress, ultrastructure

\section{INTRODUCTION}

The white-rot fungus Phanerochaete chrysosporium is able to degrade and metabolize polymeric lignin as well as a broad range of recalcitrant organopollutants (for reviews see Gold \& Alic, 1993; Reddy \& D’Souza, 1994). As such, it represents a promising candidate for bioremediation purposes (Aust, 1990; Lamar et al., 1990; Holroyd \& Caunt, 1997). Lignin peroxidase (LiP) is one of the most important of the haem proteins associated with the degradative enzyme pathway of the fungus. It oxidizes dimethoxylated aromatics to radical cations with redox potentials in excess of $1.4 \mathrm{~V}$ (Kersten et al., 1985; Bietti et al., 1998). Its value in bioremediation lies in the fact that, unlike the cytochromeP450-type enzymes linked to xenobiotic degradation, $\mathrm{LiP}$ is extracellular and uses the oxidizing power of $\mathrm{H}_{2} \mathrm{O}_{2}$ to catalyse the one-electron oxidation of its substrates via redox active mediators. The most physio-

Abbreviations: LiP, lignin peroxidase; NBT, nitro blue tetrazolium; TEM, transmission electron microscopy. logically significant of the mediators investigated to date is the fungal secondary metabolite veratryl alcohol (Harvey et al., 1986; Hammel \& Moen, 1991; Goodwin et al., 1995; Candeias \& Harvey, 1995). Redox mediation during catalysis is reflected in the apparent nonspecificity of the enzyme to its substrates and this feature lends itself to the degradation of a broad range of xenobiotics. However, commercial exploitation of the enzyme and practical applications of the fungus are limited because of the lack of knowledge about what triggers expression of the ligninolytic pathway and LiP synthesis.

In the natural environment, the fungus differentiates a thin film of mycelium to degrade lignin and metabolize cellulose. By contrast, in liquid cultures (suitable for industrial fermentation) the fungal spore inoculum develops into mycelial pellets, which are agglomerates of hyphae trapped together during germination of the spores (Gerin et al., 1993). The pellet habit represents a significant obstacle to oxygen diffusion into the hyphae (Leisola et al., 1983; Michel et al., 1992), which is essential for ligninolysis and LiP production (Kirk et al., 
1978; Bar-Lev \& Kirk, 1981; Faison \& Kirk, 1985). The role of oxygen has been ascribed to either its direct participation in ligninolysis (Kirk et al., 1978) or its capacity to promote the synthesis of one or more enzymes involved in lignin degradation (Bar-Lev \& Kirk, 1981). Alternatively, the necessity to expose fungal pellets or mats in liquid culture to a pure oxygen atmosphere has been ascribed to the need to ameliorate conditions of oxygen starvation (Leisola et al., 1983; Michel et al., 1992). To overcome the oxygen limitation to LiP production, a practice has evolved that involves exposing hyphal pellets to an atmosphere of pure oxygen when the culture medium has been depleted of carbon (supplied as glucose), nitrogen or sulphur (Kirk et al., 1978; Bar-Lev \& Kirk, 1981; Leisola \& Fiechter, 1985; Faison \& Kirk, 1985; Jager et al., 1985; Asther et al., 1987; Michel et al., 1990; Dosoretz et al., 1990; Dass \& Reddy, 1990; Bonnarme et al., 1993).

Oxygen has, however, the potential to give rise to toxic oxygen-free radicals that are capable of oxidizing, fragmenting and cross-linking proteins, carbohydrates, lipids and nucleic acids (Wolff et al., 1986). In this context, surprisingly few reports on the fungitoxic effects of exposing fungal cultures to elevated concentrations of oxygen have been made. Reid \& Seifert (1980) suggested that increasing oxygen concentration as distinct from increasing atmospheric pressure might be fungitoxic. Later, Leisola et al. (1984) found that high oxygen tensions were fungitoxic at low $(0 \cdot 1 \%, \mathrm{w} / \mathrm{v})$ glucose levels, but not at high glucose levels. They proposed that the supply of higher concentrations of glucose allowed the formation of thicker mycelia, which protected against the toxic effects of oxygen. The majority of workers in the field continue to use fungal culture conditions with excess carbon (glucose) and limiting nutrient nitrogen to trigger ligninolysis. Under this regime the fungus secretes copious amounts of extracellular polysaccharide (Buchala \& Leisola, 1987). However, frequently exposing the cultures to oxygen ultimately achieves its metabolic degradation (Dosoretz et al., 1990) so that sufficient oxygen may diffuse into the hyphae.

In this study, we looked at the intracellular architecture of fungal hyphae from agitated liquid cultures, to learn more about the interrelationship between carbon supply and oxygen in triggering ligninolysis under these conditions. We found that cultures maintained on limiting glucose and exposed to an atmosphere of pure oxygen as well as cultures maintained on cellulose showed a similar massive loss of internal organization of structure. Both cultures also produced LiP, suggesting that LiP synthesis may arise in response to oxidant stress.

\section{METHODS}

Fungal strain and growth conditions. Phanerochaete chrysosporium, strain BKM-F-1767 (ATCC 24725), was grown in liquid culture under conditions of non-limiting nutrient nitrogen, with either glucose or cellulose (Avicel) as the carbon source at a final concentration specified in the text. The growth medium had the following composition : $20 \mathrm{mM} \mathrm{NH}_{4}^{+}$, $30 \mathrm{mM}$ tartrate, $20 \mathrm{mM} \mathrm{Na}{ }^{+}, 14.7 \mathrm{mM} \mathrm{K}^{+}, 2.0 \mathrm{mM} \mathrm{\textrm {Mg } ^ { 2 + }}$, $0.73 \mathrm{mM} \mathrm{Ca}{ }^{2+}, 0.065 \mathrm{mM} \mathrm{Fe}^{3+}, 1.4 \mathrm{mM} \mathrm{Cl}^{-}, 2.0 \mathrm{mM} \mathrm{SO}_{4}^{2-}$, $2.0 \mathrm{mM} \mathrm{H}_{2} \mathrm{PO}_{4}^{-}, 64 \mu \mathrm{M}$ nitrilotriacetic acid, $1.5 \mathrm{mM}$ veratryl alcohol, trace metals and an initial $\mathrm{pH}$ of $4 \cdot 5$. All chemicals were purchased from Sigma, with the exception of Avicel PH101, which was from Fluka Chemika.

Conidiospores $\left(2 \times 10^{7}\right)$ of $P$. chrysosporium were used to inoculate $600 \mathrm{ml}$ culture medium in 21 Erlenmeyer flasks. 'Semi-static' cultures (carbon-limited) were obtained by incubating flasks in an air atmosphere at $37{ }^{\circ} \mathrm{C}$ on a rotary shaker at 150 r.p.m., $2.5 \mathrm{~cm}$ diameter cycle, for the primary phase of growth. Culture flasks were fitted with rubber stoppers through which two glass tubes fitted with gassterilizing filters were inserted. When glucose was depleted, fungal pellets were concentrated threefold for the enzyme production phase by decanting off $400 \mathrm{ml}$ medium as in Leisola et al. (1985). Flasks were then purged with $100 \%$ oxygen (10 min at $11 \mathrm{~min}^{-1}$ ), sealed under a positive pressure of oxygen and incubation was continued at 60 r.p.m. to encourage the formation of mats of mycelial growth. In cellulose-maintained cultures, flasks were closed with foam stoppers, and continuously agitated at 130 r.p.m. $(2.5 \mathrm{~cm}$ diameter cycle) $\left(37^{\circ} \mathrm{C}\right)$ in an air atmosphere throughout growth and enzyme production phases.

Enzyme assays. LiP was measured in the extracellular medium with veratryl alcohol as substrate, according to Tien \& Kirk (1984). One unit (U) of activity is defined as the amount of enzyme catalysing the oxidation of $1 \mu \mathrm{mol}$ veratryl alcohol min $^{-1}$. Extracellular glucose and $\mathrm{H}_{2} \mathrm{O}_{2}$ were determined by enzyme-coupled assay based on the Trinder colorimetric method, with 4-aminophenazone as substrate, horseradish peroxidase and, for glucose determinations, glucose oxidase, which oxidized glucose with the stoichiometric production of $\mathrm{H}_{2} \mathrm{O}_{2}$. The concentration of $\mathrm{H}_{2} \mathrm{O}_{2}$ solutions in double-distilled water was determined using $\varepsilon=0.036 \mathrm{mM}^{-1} \mathrm{~cm}^{-1}$. Residual cellulose was filtered from culture broth and from pellets extensively washed with distilled water and was estimated with $\mathrm{K}_{2} \mathrm{Cr}_{2} \mathrm{O}_{7}^{-}-\mathrm{SO}_{4}^{2-}$ reagent according to Wood \& Bhat (1988). For intracellular catalase, superoxide dismutase and protein analyses, 5-6 g mycelia was harvested, rinsed and dried with absorbent paper and mechanically ruptured in $1 \mathrm{ml}$ extract buffer $(50 \mathrm{mM}$ potassium phosphate buffer, $\mathrm{pH} 7 \cdot 5$; 0.1 mM EDTA; 0.5 mM PMSF) over liquid nitrogen. Samples were clarified at $10000 \mathrm{~g}$ for $1 \mathrm{~min}$, and assayed immediately. Catalase was measured with $\mathrm{H}_{2} \mathrm{O}_{2}(100 \mathrm{mM})$ as substrate in $50 \mathrm{mM}$ potassium phosphate buffer $(\mathrm{pH} 7 \cdot 8), 0 \cdot 1 \mathrm{mM}$ EDTA, by measuring the initial (100-200 s) linear rate of decrease in $A_{240}$ (Chance et al., 1979). One unit of catalase was defined as that amount of enzyme able to decompose $1 \mu \mathrm{mol} \mathrm{H}_{2} \mathrm{O}_{2} \mathrm{~min}^{-1}$, at $25^{\circ} \mathrm{C}$, using $\varepsilon=0.036 \mathrm{mM}^{-1} \mathrm{~cm}^{-1}$ for $\mathrm{H}_{2} \mathrm{O}_{2}$. Superoxide dismutase was assayed according to McCord \& Fridovitch (1969) by measuring the inhibition of reduction of nitro blue tetrazolium (NBT) by superoxide anions, generated by the xanthine/xanthine oxidase system. The assay mixture contained $0 \cdot 1 \mathrm{mM}$ EDTA, $0 \cdot 15 \mathrm{mM}$ xanthine, $0.15 \mathrm{mM} \mathrm{NBT}$ and $10 \mu \mathrm{l}$ xanthine oxidase in $50 \mathrm{mM}$ potassium phosphate buffer $(\mathrm{pH} 7 \cdot 5)$. The rate of reduction of NBT was monitored at $560 \mathrm{~nm}$. One unit of superoxide dismutase was defined as that amount of enzyme able to cause half-maximal inhibition of NBT reduction. The carbonyl content of proteins was measured according to Reznick \& Packer (1993) using 2,4dinitrophenylhydrazine. Protein-bound hydrazones were detected spectrophotometrically with a Perkin Elmer 555 spectrophotometer and the carbonyl content was calculated from the $A_{370}$ using an absorption coefficient for 2,4-dinitro- 

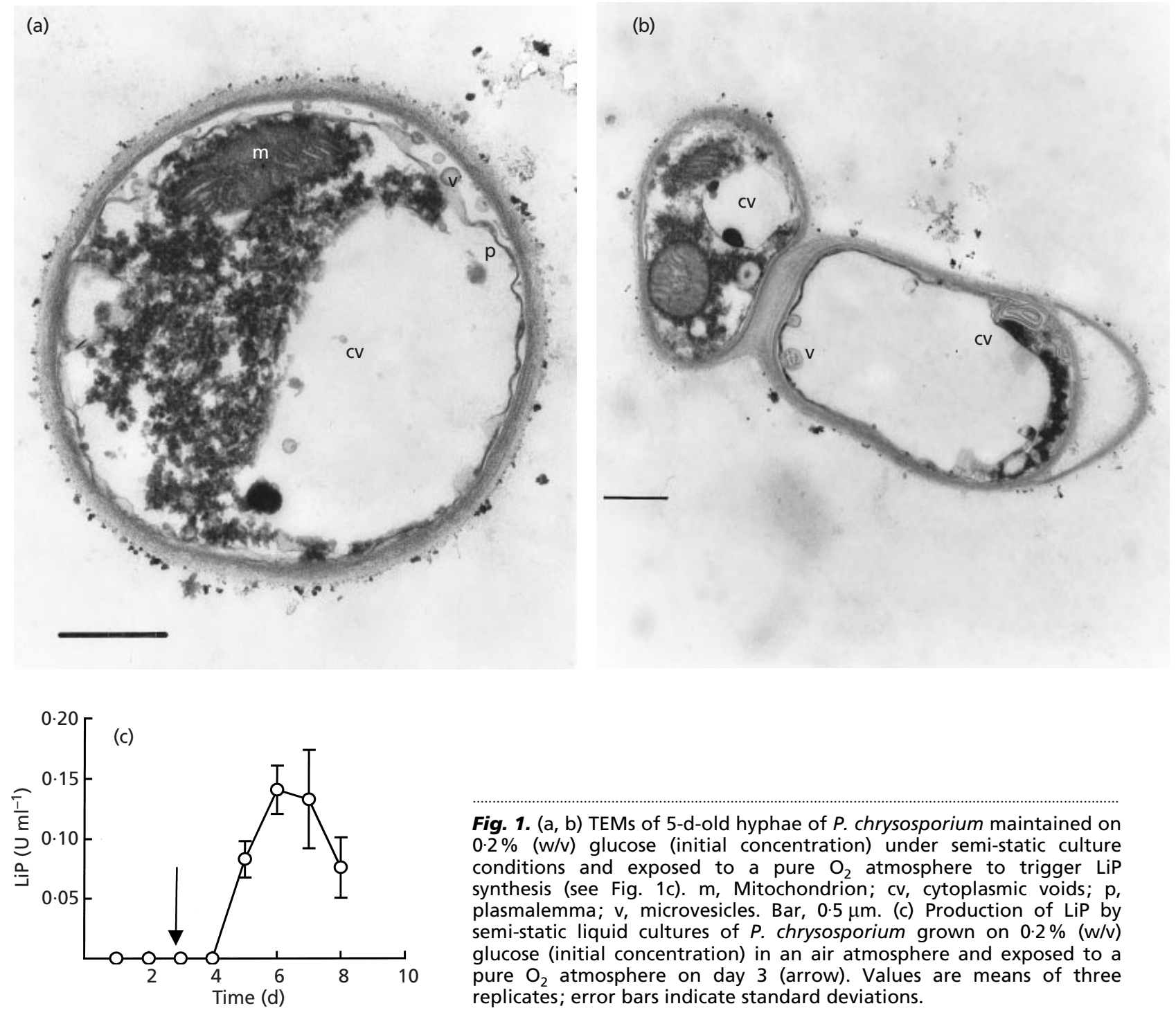

Fig. 1. $(\mathrm{a}, \mathrm{b})$ TEMs of 5-d-old hyphae of $P$. chrysosporium maintained on $0.2 \%(\mathrm{w} / \mathrm{v})$ glucose (initial concentration) under semi-static culture conditions and exposed to a pure $\mathrm{O}_{2}$ atmosphere to trigger LiP synthesis (see Fig. 1c). m, Mitochondrion; cv, cytoplasmic voids; $p$, plasmalemma; v, microvesicles. Bar, $0.5 \mu \mathrm{m}$. (c) Production of LiP by semi-static liquid cultures of $P$. chrysosporium grown on $0.2 \%(\mathrm{w} / \mathrm{v})$ glucose (initial concentration) in an air atmosphere and exposed to a pure $\mathrm{O}_{2}$ atmosphere on day 3 (arrow). Values are means of three replicates; error bars indicate standard deviations.

phenylhydrazine of $22000 \mathrm{M}^{-1} \mathrm{~cm}^{-1}$. Protein was measured by the Bradford method (1976) with ovalbumin as standard.

Transmission electron microscopy (TEM). For TEM, samples were fixed for $4 \mathrm{~h}$ at room temperature in $2 \%(\mathrm{v} / \mathrm{v})$ paraformaldehyde containing $2.5 \%(\mathrm{v} / \mathrm{v})$ glutaraldehyde in $0.1 \mathrm{M}$ phosphate buffer $(\mathrm{pH} 4 \cdot 5)$. The material was washed twice with $0 \cdot 1 \mathrm{M}$ phosphate buffer and post-fixed in $1 \%(\mathrm{v} / \mathrm{v})$ osmium tetroxide in phosphate buffer $(\mathrm{pH} 4 \cdot 5)$ for $1 \mathrm{~h}$ at $4{ }^{\circ} \mathrm{C}$, then rinsed with buffer, then distilled water, and stained in $2 \%$ $(\mathrm{w} / \mathrm{v})$ uranyl acetate in $70 \%(\mathrm{v} / \mathrm{v})$ ethanol for $15 \mathrm{~min}$ at room temperature. Thereafter, samples were dehydrated in an ethanol series $(70-100 \%, 10 \%$ steps for $10 \mathrm{~min})$ and embedded in Agar 100 resin (Agar 100 Resin kit from Agar Scientific). The material was sectioned with a Reichert Ultracut. Hyphal sections were obtained from the outer cortex of the pellets. Initially, 2- $\mu$ m-thick sections were cut and observed under a light microscope. The staining with $0.5 \%(\mathrm{w} / \mathrm{v})$ methylene blue, $0.5 \%(\mathrm{w} / \mathrm{v})$ azure II, $0.5 \%$ borax revealed when sections contained fungal material, at which point thin sections for TEM studies (50-70 nm thick) were collected on nickel grids. At least 25 sections of each type of fungal material were observed under the electron microscope. Before TEM observations, grids were stained in $2 \%(\mathrm{w} / \mathrm{v})$ uranyl acetate and lead citrate (Reynolds, 1963). TEM studies were carried out with a Philips 400T transmission electron microscope, using an accelerating voltage of $80 \mathrm{kV}$.

\section{RESULTS AND DISCUSSION}

Fungal cells were obtained from 5-d-old liquid cultures that were actively secreting LiP following their exposure to a pure oxygen atmosphere when the carbon source was depleted (Fig. 1c), and their ultrastructure was compared with cells that were not producing LiP (Fig. $2 \mathrm{a}, \mathrm{b})$. Fig. 1(a,b) typifies the appearance of cells exposed to an atmosphere of pure oxygen. Extensive degeneration of the cytoplasm is evident: the plasmalemma (p) has shrunk from the hyphal wall; half of the cytosol has disintegrated (cv); microvesicles (v), probably with autolytic functions, are recognizable on the periphery of the cell; and the cytoplasm is entirely 

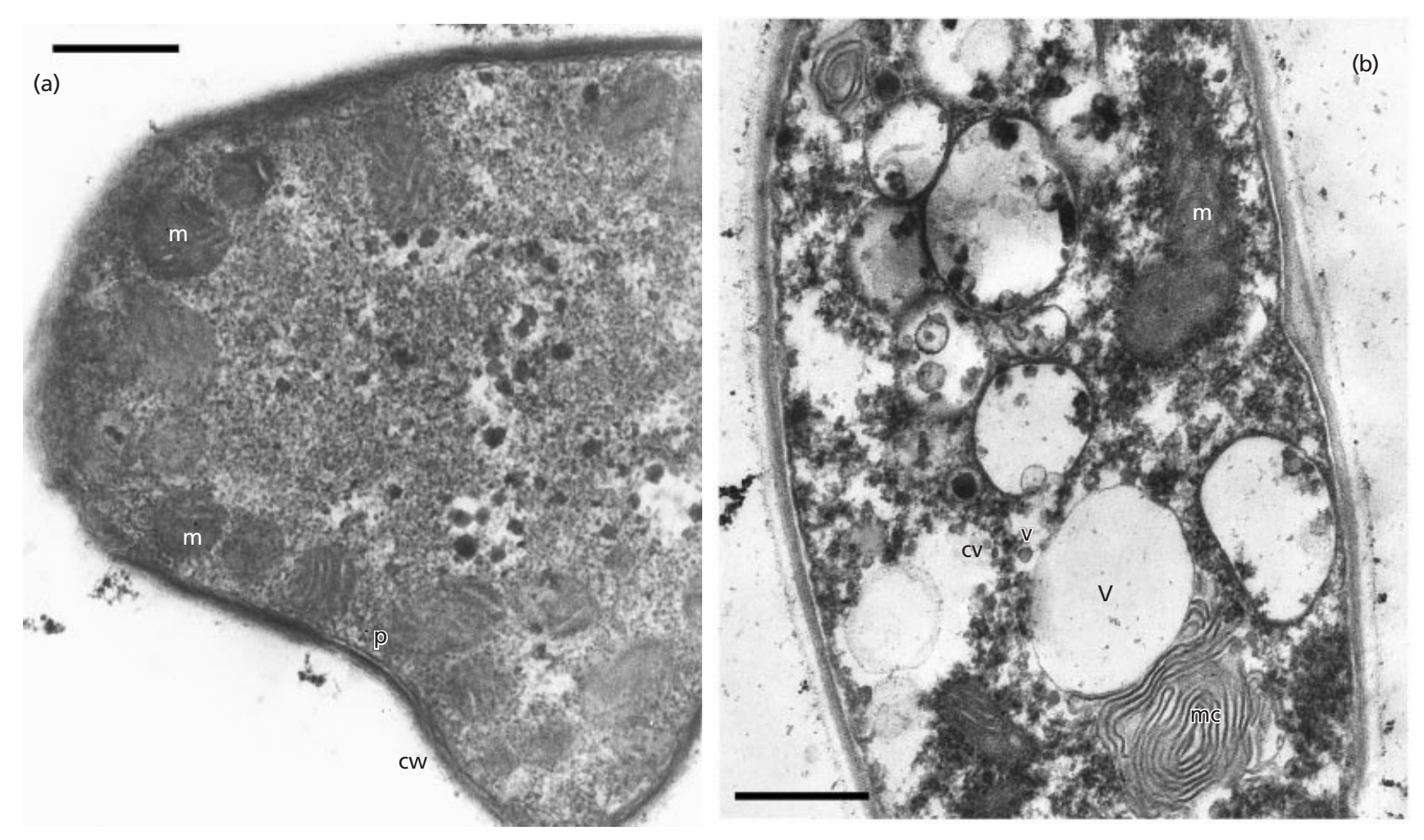

Fig. 2. (a, b) TEMs of non-ligninolytic hyphae of $P$. chrysosporium. Two morphological types are depicted: cells with continuous cytoplasm and no signs of degeneration (a) and cells undergoing autolysis (b). These figures were prepared from cultures after $4 \mathrm{~d}$ growth in an air atmosphere with $0.4 \%(\mathrm{w} / \mathrm{v})$ glucose (initial concentration). cw, Cell wall; $\mathrm{V}$, vacuole; v, vesicles; $\mathrm{m}$, mitochondrion; cv, cytoplasmic void; mc, multi-membrane complex. Bar, $0.5 \mu \mathrm{m}$.

coagulated. Only mitochondria (m), the sites for oxygen reduction to water, were consistently found to have retained their internal organization. These features were observed in at least 25 different sections, suggesting that they were not restricted to the oldest parts of the mycelium, but were widespread throughout the cortex of mycelial pellets. By contrast, when samples were taken from non-ligninolytic cell populations that had not been exposed to pure oxygen, over the time frame of $3-5 \mathrm{~d}$ growth in either $0.2 \%(\mathrm{w} / \mathrm{v})$ or $0.4 \%(\mathrm{w} / \mathrm{v})$ glucose, two distinct fungal growth conditions were revealed. The section shown in Fig. 2(a) is typical of hyphae of the first morphological type. The cytoplasm is homogeneously electron-dense, there are few vacuoles and vesicles, and the plasmalemma is seen to adhere to the cell wall. Numerous mitochondria $(\mathrm{m})$ confined at the periphery of the cytoplasm can be identified by the presence of well-defined cristae which are arranged parallel to the long axis of the organelle. Fig. 2(b) typifies sections from the second morphological type representing cells undergoing autolysis. Fungal cells within a single mycelium are known to autolyse to provide nutrients to ensure growth or maintenance in the absence of external nutrients (Trinci \& Righelato, 1970; Trinci \& Thurston, 1976). Fig. 2(b) shows the presence of numerous vacuoles $(\mathrm{V})$ and vesicles $(\mathrm{v})$, and, in the cytoplasm, autolytic regions (cv) and protein aggregates. An elongated mitochondrion $(\mathrm{m})$ is visible along the cell wall, with an identifiable internal orthodox organization. Multi-membrane complexes (mc) are also visible, possibly representing a reservoir of material for membrane-delimited cytoplasmic structures (Trinci \& Righelato, 1970; Markham, 1995). Despite a search to show the contrary, cells from non-ligninolytic cultures never reached the extreme level of appearance that was observed for cells exposed to a pure oxygen atmosphere, typified by Fig. 1(a, b).

These results confirmed the toxic effects of exposing cultures to pure oxygen. Exposure to pure oxygen, apart from triggering LiP synthesis, caused an alteration of cellular architecture. This is consistent with reports of a flux of nitrogen into the extracellular medium by cultures exposed to pure oxygen to induce ligninolysis (Jeffries et al., 1981), the development of conidiospores in the mycelium (Bonnarme et al., 1993), and extracellular presence of $\mathrm{H}_{2} \mathrm{O}_{2}$ (Tonon \& Odier, 1988; Kern, 1989).

In light of these results, it was of interest to investigate the intracellular architecture of cultures that synthesized LiP without exposing them to a pure oxygen atmosphere. For this purpose, we selected liquid cultures agitated in air with cellulose as the carbon source. Sections were taken from the outer region of pellets 

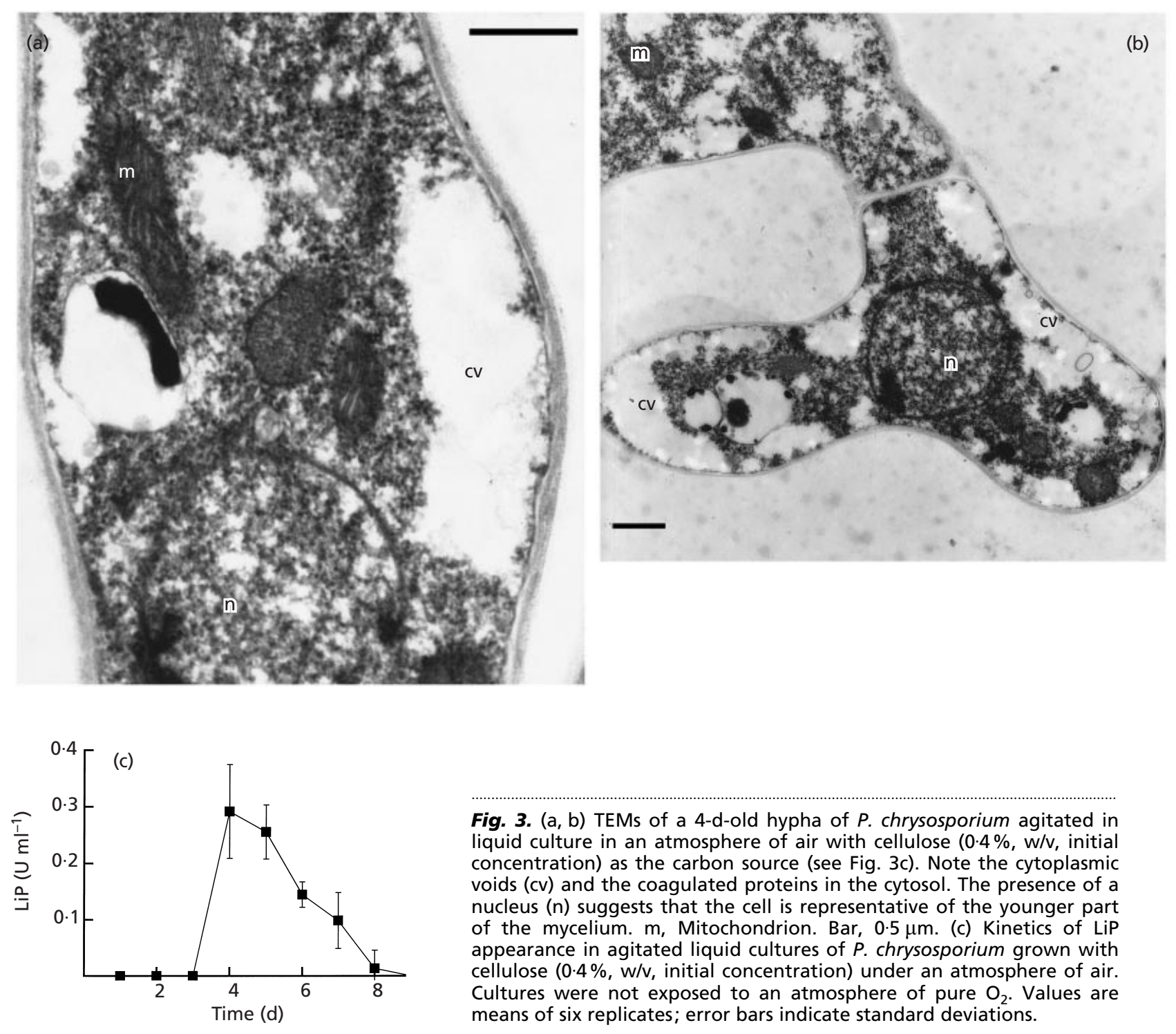

Fig. 3. (a, b) TEMs of a 4-d-old hypha of $P$. chrysosporium agitated in liquid culture in an atmosphere of air with cellulose $(0.4 \%, \mathrm{w} / \mathrm{v}$, initial concentration) as the carbon source (see Fig. 3c). Note the cytoplasmic voids (cv) and the coagulated proteins in the cytosol. The presence of a nucleus $(n)$ suggests that the cell is representative of the younger part of the mycelium. m, Mitochondrion. Bar, $0.5 \mu \mathrm{m}$. (c) Kinetics of LiP appearance in agitated liquid cultures of $P$. chrysosporium grown with cellulose $(0.4 \%, w / v$, initial concentration) under an atmosphere of air. Cultures were not exposed to an atmosphere of pure $\mathrm{O}_{2}$. Values are means of six replicates; error bars indicate standard deviations.

sampled on day 4 when LiP was detected in the extracellular medium (see Fig. 3c). The representative micrographs in Fig. 3(a, b) illustrate that these hyphae showed a remarkable similarity to those exposed to pure oxygen. Irregularly shaped electron-translucent areas or voids $(\mathrm{cv})$ in the cytoplasm that are not surrounded by a membrane are evident, as well as electron-dense particles, possibly cytoplasmic protein aggregates. Cytologically 'normal' hyphae as depicted in Fig. 2(a,b) were never observed. Mitochondria $(\mathrm{m})$ maintained an orthodox organization, as before, with the cristae visible as lamellae parallel to the long axis of the organelle, in a configuration typical of filamentous fungi (Markham, 1995). In this micrograph, the presence of a nucleus (n) indicates that the cell is part of the younger mycelium, and not of an ageing hyphal network.

The disrupted intracellular architecture in the agitated cultures maintained on cellulose suggested that a hyper- oxidant state of growth, caused by limiting respirable carbon, might have arisen in these cultures (Hansberg \& Aguirre, 1990). Properties diagnostic of a hyperoxidant condition were therefore investigated both in the cultures maintained on cellulose and, for comparison, in cultures maintained under the same conditions but with glucose as the carbon source, which had shown a more organized ultrastructure (see Fig. 2). Fig. 4 shows that levels of intracellular catalase were up to 20 -fold higher by the fourth day of growth $\left[8 \cdot 8 \pm 4 \cdot 3 \mathrm{U}(\mu \mathrm{g} \text { protein })^{-1}\right]$ in the cellulose-maintained cultures compared to glucose $\left[0 \cdot 413 \pm 0.3 \mathrm{U}(\mu \mathrm{g} \text { protein })^{-1}\right]$, reaching $10 \cdot 4 \mathrm{U}$ ( $\mu \mathrm{g}$ protein $)^{-1}$ by the fifth day of growth. In glucose-grown cultures, catalase levels increased as extracellular glucose levels declined, a similar trend to observations reported for catalase in Escherichia coli (Hassan \& Fridovich, 1978), but never reached the levels recorded in cellulose-maintained hyphae. Marked differences were also found in levels of extracellular $\mathrm{H}_{2} \mathrm{O}_{2}$ between 


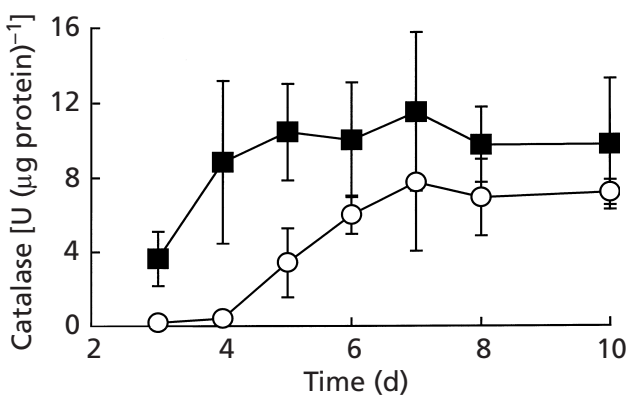

Fig. 4. Levels of intracellular catalase in submerged liquid cultures of $P$. chrysosporium agitated in an air atmosphere with either cellulose $(\boldsymbol{\square})$ or glucose $(O)$ as the carbon source. Both carbon sources had an initial concentration of $0.4 \%(\mathrm{w} / \mathrm{v})$. Values are means of five replicates; error bars indicate standard deviations.

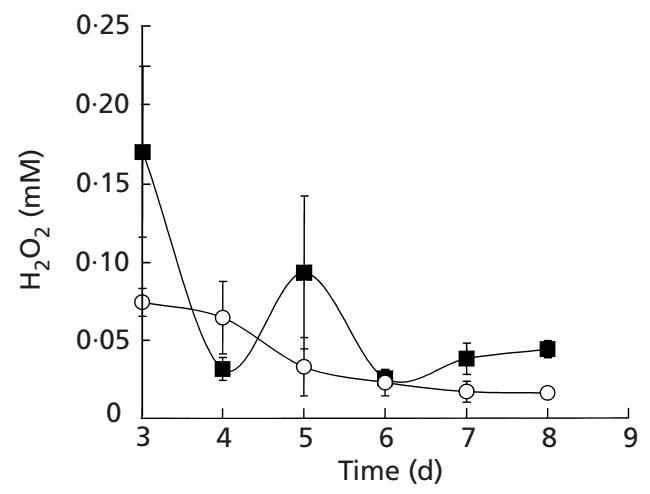

Fig. 5. Extracellular concentration of $\mathrm{H}_{2} \mathrm{O}_{2}$ in submerged liquid cultures of $P$. chrysosporium agitated in an air atmosphere with either cellulose $(\boldsymbol{\square})$ or glucose $(O)$ as the carbon source. Both carbon sources were supplied at an initial concentration of $0.4 \%(\mathrm{w} / \mathrm{v})$. Values are means of three replicates; error bars indicate standard deviations.

glucose- and cellulose-maintained cultures (see Fig. 5). On the third day of growth the level of $\mathrm{H}_{2} \mathrm{O}_{2}$ in cellulose-maintained cultures $(0 \cdot 17 \pm 0 \cdot 051 \mathrm{mM} ; n=3$; $\pm \mathrm{SD})$ was more than double that found in glucosesufficient cultures $(0 \cdot 07 \pm 0.008 \mathrm{mM} ; n=3 ; \pm \mathrm{SD})$, but declined sharply with the appearance of LiP to $0.03 \pm 0.007 \mathrm{mM}(n=3 ; \pm \mathrm{SD})$. This is in line with the catalytic activity of LiP in reducing $\mathrm{H}_{2} \mathrm{O}_{2}$ to water. In both cultures, the level of superoxide dismutase was similar, increasing only slightly from $100 \pm 10 \mathrm{U}$ (mg protein $)^{-1}$ on the third day of growth to approximately $160 \mathrm{U}$ (mg protein $)^{-1}$ as the carbon source from each culture was depleted. These relatively constant levels infer that levels of this enzyme were not limiting, in line with its importance in protection against the potentially damaging effects of superoxide radicals (McCord \& Fridovitch, 1969). When the carbonyl content of intracellular proteins was examined, no difference could be detected between non-stressed and stressed cells up to the fifth day of growth $\left[3-5 \mathrm{nmol}(\mathrm{mg} \text { protein })^{-1}\right.$ for days 3-5]. However, on the sixth day of growth the level recorded for the cellulose-maintained cultures doubled to $10 \pm 1 \cdot 3 \mathrm{nmol}(\mathrm{mg} \text { protein })^{-1}$ compared to the control. The increase detected in carbonyl content is much later than the appearance of LiP (day 4), inferring irreversible breakdown of the cell at this time.

Both these results and the observations of cellular architecture suggest that cultures agitated with cellulose as the carbon source developed a hyperoxidant state. The most likely explanation is that the rate of supply of carbon from cellulose hydrolysis was insufficient to maintain the intracellular NADH pool at a concentration required for oxygen homeostasis during air agitation. Significantly, these conditions also led to the appearance, in the extracellular medium, of LiP. LiP is also produced in cultures exposed to a pure oxygen atmosphere, which was demonstrated in this paper to inflict massive cellular damage. These data together suggest that LiP may be an enzyme that is induced under conditions of oxidant stress to reduce the levels of extracellular $\mathrm{H}_{2} \mathrm{O}_{2}$ as well as, in vivo, to degrade lignin to access further sources of carbon.

\section{ACKNOWLEDGEMENTS}

We would like to thank J. M. Palmer for critical reading of the manuscript.

\section{REFERENCES}

Asther, M., Corrieu, G., Drapon, R. \& Odier, E. (1987). Effect of Tween 80 and oleic acid on ligninase production by Phanerochaete chrysosporium INA-12. Enzyme Microb Technol 9, 245-249.

Aust, S. D. (1990). Degradation of environmental pollutants by Phanerochaete chrysosporium. Microb Ecol 20, 197-209.

Bar-Lev, S. S. \& Kirk, T. K. (1981). Effects of molecular oxygen on lignin degradation. Biochim Biophys Res Commun 99, 373-378.

Bietti, M., Baciocchi, E. \& Steenken, S. (1998). Lifetime, reduction potential and base-induced fragmentation of the veratryl alcohol radical cation in aqueous solution. Pulse radiolysis studies on a ligninase 'mediator'. J Phys Chem A 102, 7337-7342.

Bonnarme, P., Delattre, M., Drouet, H., Corrieu, G. \& Asther, M. (1993). Toward a control of lignin and manganese peroxidases hypersecretion by Phanerochaete chrysosporium in agitated vessels: evidence of the superiority of pneumatic bioreactors on mechanically agitated bioreactors. Biotechnol Bioeng 41, 440450.

Bradford, M. (1976). A rapid and sensitive method for the quantitation of microgram quantities of proteins utilizing the principle of protein-dye binding. Anal Biochem 72, 248-254.

Buchala, A. J. \& Leisola, M. S. A. (1987). Structure of the $\beta$-Dglucan secreted by Phanerochaete chrysosporium in continuous culture. Carbohydr Res 165, 146-149.

Candeias, L. P. \& Harvey, P. J. (1995). Lifetime and reactivity of the veratryl alcohol radical cation. J Biol Chem 270, 16745-16748.

Chance, B., Sies, H. \& Boveris, A. (1979). Hydroperoxide metabolism in mammalian organs. Physiol Rev 59, 527-605.

Dass, S. B. \& Reddy, C. A. (1990). Characterisation of extracellular peroxidases produced by acetate-buffered cultures of the lignindegrading basidiomycete Phanerochaete chrysosporium. FEMS Microbiol Lett 69, 221-224. 
Dosoretz, C. G., Chen, A. H.-C. \& Grethlein, H. E. (1990). Effect of oxygenation conditions on submerged cultures of Phanerochaete chrysosporium. Appl Microbiol Biotechnol 34, 131-137.

Faison, B. D. \& Kirk, T. K. (1985). Factors involved in the regulation of ligninase activity in Phanerochaete chrysosporium. Appl Environ Microbiol 49, 299-304.

Gerin, P. A., Bellon-Fontaine, M.-N., Asther, M. \& Rouxhet, P. G. (1993). Surface properties of the conidiospores of Phanerochaete chrysosporium and their relevance to pellet formation. J Bacteriol $175,5135-5144$.

Gold, M. H. \& Alic, M. (1993). Molecular biology of the lignindegrading basidiomycete Phanerochaete chrysosporium. Microbiol Rev 57, 605-622.

Goodwin, D. C., Aust, S. D. \& Grover, T. A. (1995). Evidence for veratryl alcohol as a redox mediator in lignin peroxidasecatalysed oxidation. Biochemistry 34, 5060-5065.

Hammel, K. E. \& Moen, M. A. (1991). Depolymerization of a synthetic lignin in vitro by lignin peroxidase. Enzyme Microb Technol 13, 15-18.

Hansberg, W. \& Aguirre, J. (1990). Hyperoxidant states cause microbial cell differentiation by cell isolation from dioxygen. $J$ Theor Biol 142, 201-221.

Harvey, P. J., Schoemaker, H. E. \& Palmer, J. M. (1986). Veratryl alcohol as a mediator and the role of radical cation in lignin biodegradation by Phanerochaete chrysosporium. FEBS Lett 195, 242-246.

Hassan, H. M. \& Fridovitch, I. (1978). Regulation of the synthesis of catalase and peroxidase in E. coli. J Biol Chem 253, 6445-6450.

Holroyd, M. L. \& Caunt, P. (1997). Field-scale use of white rot fungi for soil remediation in Finland. In Bioremediation: Principles and Practice III, pp. 245-257. Edited by S. K. Sikdar \& R. L. Irvine. Lancaster, PA: Technomic Publishing.

Jager, A., Croan, S. \& Kirk, T. K. (1985). Production of ligninases and degradation of lignin in agitated submerged cultures of Phanerochaete chrysosporium. Appl Environ Microbiol 50, 1274-1278.

Jeffries, T. W., Choi, S. \& Kirk, T. K. (1981). Nutritional regulation of lignin degradation by Phanerochaete chrysosporium. Appl Environ Microbiol 42, 290-296.

Kern, H. W. (1989). Improvement in the production of extracellular lignin peroxidases by Phanerochaete chrysosporium: effect of solid manganese(IV)oxide. Appl Microbiol Biotechnol 32, 223-234.

Kersten, P. J., Tien, M., Kalayanaraman, B. \& Kirk, T. K. (1985). The ligninase of Phanerochaete chrysosporium generates cation radicals from methoxybenzenes. J Biol Chem 260, 2609-2612.

Kirk, T. K., Schultz, E., Connors, W. J., Lorenz, L. F. \& Zeikus, J. G. (1978). Influence of culture parameters on lignin metabolism by Phanerochaete chrysosporium. Arch Microbiol 117, 277-285.

Lamar, R. T., Glaser, J. A. \& Kirk, T. K. (1990). Fate of pentachlorophenol (PCP) in sterile soils inoculated with the white-rot basidiomycete Phanerochaete chrysosporium: mineralization, volatilization and depletion of PCP. Soil Biol Biochem 22, 433-440.

Leisola, M. S. A. \& Fiechter, A. (1985). Ligninase production in agitated condition by Phanerochaete chrysosporium. FEMS Microbiol Lett 29, 33-36.
Leisola, M. S. A., Ulmer, D. \& Fiechter, A. (1983). Problem of oxygen transfer during degradation of lignin by Phanerochaete chrysosporium. Eur J Microbiol Biotechnol 17, 113-116.

Leisola, M. S. A., Ulmer, D. \& Fiechter, A. (1984). Factors affecting lignin degradation in lignocellulose by Phanerochaete chrysosporium. Arch Microbiol 137, 171-175.

Leisola, M. S. A., Thanei-Wyss, U. \& Fiechter, A. (1985). Strategies for production of high ligninase activities by Phanerochaete chrysosporium. J Biotechnol 3, 97-107.

McCord, J. M. \& Fridovitch, I. (1969). Superoxide dismutase. An enzymic function for erythrocuprein (hemocuprein). J Biol Chem 244, 6049-6055.

Markham, P. (1995). Organelles of filamentous fungi. In The Growing Fungus, pp. 75-98. Edited by N. A. R. Gow \& G. M. Gadd. London: Chapman \& Hall.

Michel, F. C., Grulke, E. A. \& Reddy, C. A. (1990). Development of a stirred tank reactor system for the production of lignin peroxidases (ligninases) by Phanerochaete chrysosporium BKMF-1767. J Ind Microbiol 5, 103-112.

Michel, F. C., Grulke, E. A. \& Reddy, C. A. (1992). Determination of the respiratory kinetics for mycelial pellets of Phanerochaete chrysosporium. Appl Environ Microbiol 58, 1740-1745.

Reddy, C. A. \& D'Souza, T. M. (1994). Physiology and molecular biology of the lignin peroxidases of Phanerochaete chrysosporium. FEMS Microbiol Rev 13, 137-152.

Reid, I. D. \& Seifert, K. A. (1980). Lignin degradation by Phanerochaete chrysosporium in hyperbaric oxygen. Can J Microbiol 26, 1168-1171.

Reynolds, E. S. (1963). The use of lead citrate at high $\mathrm{pH}$ as an electron-opaque stain in electron microscopy. J Cell Biol 17, 208-212.

Reznick, A. Z. \& Packer, L. (1993). Oxidative damage to proteins: spectrophotometric method for carbonyl assay. Methods Enzymol 233, 346-357.

Tien, M. \& Kirk, T. K. (1984). Lignin-degrading enzyme from Phanerochaete chrysosporium. Purification, characterization, and catalytic properties of a unique $\mathrm{H}_{2} \mathrm{O}_{2}$-requiring oxygenase. Proc Natl Acad Sci USA 81, 2280-2284.

Tonon, F. \& Odier, E. (1988). Influence of veratryl alcohol and hydrogen peroxide on ligninase production by Phanerochaete chrysosporium. Appl Environ Microbiol 54, 466-472.

Trinci, A. P. J. \& Righelato, R. C. (1970). Changes in constituents and ultrastructure of hyphal compartments during autolysis of glucose-starved Penicillium chrysogenum. J Gen Microbiol 60, 239-249.

Trinci, A. P. J. \& Thurston, C. F. (1976). Transition to the nongrowing state in eukaryotic micro-organisms. Symp Soc Gen Microbiol 26, 55-80.

Wolff, S. P., Garner, A. \& Dean, R. T. (1986). Free radicals, lipids and protein degradation. Trends Biochem Sci 11, 27-31.

Wood, T. M. \& Bhat, K. M. (1988). Methods for measuring cellulase activities. Methods Enzymol 160, 87-117.

Received 16 August 1999; revised 18 November 1999; accepted 2 December 1999. 